\section{Commentary: Complex aortic valve-sparing root operations in congenital heart disease: Are we unintentionally creating a monster?}

\author{
Bahaaldin Alsoufi, MD
}

Aortic root pathology is especially important in adult cardiac surgery. Aortic root dilation and aneurysm formation can create significant morbidity via multiple mechanisms, including the development of aortic regurgitation, rupture, dissection, or compression of adjacent structures. Aortic root replacement that includes the aortic valve was considered the standard operation for decades. ${ }^{1}$ Aortic valvesparing root (AVSR) operations were introduced in the early 1990s as surgical alternatives that allowed root replacement with repair and preservation of the native aortic valve. ${ }^{2,3}$ Despite the complexity and needed expertise, AVSR evolved to become the procedure of choice by many surgeons for the management of aortic root dilation and aneurysm.

Although the indications for aortic root surgery are well defined in adults, the literature for indications in children remains relatively deficient, and most of the recommendations are copied from those established for adult patients. In the current issue of the Journal, Buratto and Konstantinov ${ }^{4}$ from Melbourne provide a nice review of existing works on AVSR in children and focus on current information regarding indications, techniques, and early and late results in children and adults with congenital heart disease. ${ }^{4}$ In their review, the authors describe indications for surgery that are derived from adults and available results from the few reports that are dedicated mainly to this patient

\footnotetext{
From the Department of Cardiovascular and Thoracic Surgery, University of Louisville School of Medicine, Norton Children's Hospital, Louisville, Ky.

Disclosures: The author reported no conflicts of interest.

The Journal policy requires editors and reviewers to disclose conflicts of interest and to decline handling or reviewing manuscripts for which they may have a conflict of interest. The editors and reviewers of this article have no conflicts of interest.

Received for publication Sept 20, 2020; revisions received Sept 20, 2020; accepted for publication Sept 23, 2020; available ahead of print Sept 28, 2020.

Address for reprints: Bahaaldin Alsoufi, MD, Department of Cardiovascular and Thoracic Surgery, University of Louisville School of Medicine, Norton Children's Hospital, 201 Abraham Flexner Way, Suite 1200, Louisville, KY 40202 (E-mail: balsoufi@hotmail.com).

J Thorac Cardiovasc Surg 2021;162:963-4

$0022-5223 / \$ 36.00$

Copyright (c) 2020 by The American Association for Thoracic Surgery

https://doi.org/10.1016/j.jtcvs.2020.09.084
}

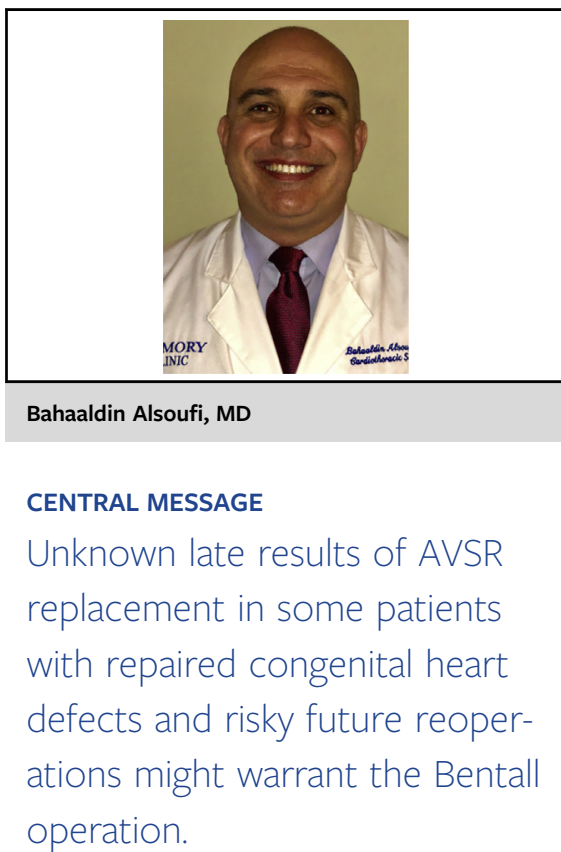

population. The main points that can be concluded from their review are the following: (1) As in adults, connective tissue disease is the most common indication for AVSR. In these patients, AVSR is associated with excellent results similar to those reported in adult patients..$^{5}$ (2) AVSR has been applied increasingly in a unique subset of patients with repaired congenital heart disease (eg, conotruncal anomalies such as transposition, common arterial trunk and tetralogy, single ventricle, after Ross procedure for congenital aortic valve disease) who develop aortic root dilation \pm aortic regurgitation. (3) There are no guidelines for aortic root surgery in patients with repaired congenital heart disease, and the indications have largely followed those for connective tissue disease despite the fact that reports of dissection or rupture in these patients have been rare.

Two points are worthy of discussion: The first is the lack of evidence that root or neoaortic root dilation in repaired congenital heart disease would expose the patients to risks of rupture or dissection. The presence of adhesions that might provide external support to the root and the suture lines that might prevent progression of dissection could decrease the risk of devastating complications in these patients. On this basis, one might argue that reoperation indication in these patients should be based on the presence of aortic regurgitation and not on the root size. Additionally, a simpler and safer reoperation such as aortic valve replacement without a root operation might be sufficient. In a review from Riyadh, Saudi Arabia, 50 patients underwent autograft valve replacement alone after the Ross procedure. 
Although serial echocardiograms demonstrated a progressive but small increase of the remaining root averaging $0.2 \mathrm{~cm}$ per year, the freedom from root reoperation was $98 \%$ at 10 years with no reports of late deaths related to root complications. ${ }^{6}$ Another study from the Mayo Clinic examined 81 patients with repaired conotruncal anomalies who had aortic reoperations, including 63 who had isolated aortic valve repair or replacement. None of these patients needed aortic root reoperation or developed dissection on follow-up. ${ }^{7}$ These studies might again give support to the simplistic management of late aortic regurgitation in these patients and expectant management of aortic and neoaortic root dilation.

The second point is the complicated nature of possible future reoperation after AVSR in these complex patients with repaired congenital heart disease. In the best hands, redo root operation is associated with high operative mortality. ${ }^{8,9}$ In a review of 473 patients who required Bentall operation after prior cardiac surgery at an experienced center in Toronto, only $77 \%$ of the patients had direct coronary implantation (reflecting the complexity of these operations) and operative mortality was high $(7.8 \%)$, with those who required different coronary implantation techniques being at higher risk. ${ }^{9}$ Although the results of AVSR in patients with connective tissue disease are good and well known, and reoperation risk has been low, the long-term results in patients with repaired congenital heart disease who undergo AVSR are unknown and additional future reoperations in these patients are definitely more complex. ${ }^{2,5,8,9}$ If these patients develop aortic valve failure after AVSR (eg, a patient with common arterial trunk or transposition who underwent AVSR and presented few years later with aortic regurgitation), redo operations are expected to be especially complex and risky. In these patients, redo repair of the aortic valve is often not feasible and valve replacement might require a redo root operation. By pushing AVSR in these patients, we might be creating a "monster" composed of a subset of patients who would be extremely challenging or even inoperable in the future. When we offer valve options to patients, the magnitude and risk of future reoperation are often overlooked. We also tend to ignore that despite the need for anticoagulation and the small thromboembolic risk, survival after the Bentall is excellent and comparable to AVSR. ${ }^{1,10}$ These patients might be better served with an operation that might give them the best chance to avoid this risky reoperation in the future, and in my opinion, that is the Bentall operation.

AVSR in children with connective tissue disease is feasible and should be considered as first-line therapy. In the more complex patients with repaired congenital heart disease, long-term efficacy of AVSR is unknown, and thoughtful consideration should be done when offering AVSR that takes into consideration the likelihood of achieving durable aortic valve repair and the risk and complexity of future cardiac reoperation.

\section{References}

1. Cameron DE, Alejo DE, Patel ND, Nwakanma LU, Weiss ES, Vricella LA, et al Aortic root replacement in 372 Marfan patients: evolution of operative repair over 30 years. Ann Thorac Surg. 2009;87:1344-50.

2. David TE, David CM, Feindel CM, Manlhiot C. Reimplantation of the aortic valve at 20 years. J Thorac Cardiovasc Surg. 2017;153:232-8.

3. Yacoub MH, Gehle P, Chandrasekaran V, Birks EJ, Child A, Radley-Smith R Late results of a valve-preserving operation in patients with aneurysms of the ascending aorta and root. J Thorac Cardiovasc Surg. 1998;115:1080-90.

4. Buratto E, Konstantinov IE. Valve-sparing aortic root surgery in children and adults with congenital heart disease. J Thorac Cardiovasc Surg. 2021;162: 955-62.

5. Fraser CD III, Liu RH, Zhou X, Patel ND, Lui C, Suarez Pierre A, et al. Valvesparing aortic root replacement in children: outcomes from 100 consecutive cases. J Thorac Cardiovasc Surg. 2019;157:1100-9.

6. Alsoufi B, Ahmed D, Manlhiot C, Al-Halees Z, McCrindle BW, Fadel BM. Fate of the remaining neo-aortic root after autograft valve replacement with a stented prosthesis for the failing ross procedure. Ann Thorac Surg. 2013;96: $59-65$.

7. Stulak JM, Dearani JA, Burkhart HM, Sundt TM, Connolly HM, Schaff HV. Does the dilated ascending aorta in an adult with congenital heart disease require intervention? J Thorac Cardiovasc Surg. 2010;140(6 Suppl):S52-91.

8. Alsoufi B, Fadel B, Bulbul Z, Al-Ahmadi M, Al-Fayyadh M, Kalloghlian A, et al. Cardiac reoperations following the Ross procedure in children: spectrum of surgery and reoperation results. Eur J Cardiothorac Surg. 2012;42:25-31.

9. Mazine A, David TE, Lafreniere-Roula M, Feindel CM, Ouzounian M. Early outcomes of the Bentall procedure after previous cardiac surgery. J Thorac Cardiovasc Surg. March 25, 2020 [Epub ahead of print].

10. Leontyev S, Schamberger L, Davierwala PM, Von Aspern K, Etz C, Lehmann S, et al. Early and late results after David vs Bentall procedure: a propensity matched analysis. Ann Thorac Surg. 2020;110:120-6. 